\title{
Correspondence
}

\section{British polar expeditions 1919-39: a comment}

\author{
Alexander Glen \\ The Dower House, Stanton, Broadway, Worcestershire \\ WR 127 NE.
}

\section{Received May 1990}

John Wright's precise and fascinating summary of British expeditions to the Arctic between 1919 and 1939 (Polar Record 26(157): 77-84, April 1990) makes excellent reading. He will forgive me, I hope, if I find some names missing, including Erich Etienne, a member of the 1938 West Greenland expedition. He was later in charge of German operations in Svalbard in 1942, a friend of many and a respected adversary - killed, sadly, far too young.

It is interesting to note the many characteristics common to these expeditions: concentration on selected objectives, a total absence of the hype more usual today, economy, and - most marked - youth in leadership. Initiative and self resource were great, and it is all the more remarkable, given the scale of enterprise, that out of 260 who travelled in the arctic lands over these 20 years only four lost their lives, all in the summer.

John Wright invites wider comment and there are two points which one might make. As he says, effective radio communication between base and travelling units using light-weight sets was never achieved. This was disappointing because much had been learnt about frequencies and ionospheric circumstances from Appleton and Watson Watt. In our own case we did our utmost to persuade manufacturers to provide prototypes, but despite guidance from experts such as Clive Lochnis and Patrick de Laszlo, no progress resulted.

This was to have wider consequences. For far too long agents infiltrated after 1939 into occupied territory had to lug around heavy suitcase transmitters of dubious capacity. I have always regretted the failure to use the Arctic for light-weight radio development.

I would return to the most significant character of the 1919-39 expeditions, youth in leadership. John Wright correctly emphasises the great credit due Frank Debenham and James Wordie in Cambridge, and Charles Elton and Kenneth Sandford in Oxford. But I would suggest there was something more, a remarkable attitude of mind, an enthusiasm and especial vigour in the RGS of that time. David Haig Thomas in his book pays his own moving tribute to Arthur Hinks, that great Edwardian figure, generous in heart no matter how penetrating (and even at times alarming) he could be in questioning. With Presidents such as Admiral Sir William Goodenough, the kindly Henry Balfour and the legendary Sir Percy Cox, men of courtesy always with time to give, we young men of the 1930s were fortunate indeed.

In gratitude for their confidence in us, I most earnestly hope that the Scott Polar Institute and the RGS can count over the years ahead on the resources, material and human, to encourage and support young people in these same ways. And I hope too that both will flourish as centres of international excellence in their activities of growing global importance.

\section{Two further British expeditions}

\section{G. Hattersley-Smith}

The Crossways, Cranbrook, Kent TN17 2AG

\section{Received May 1990}

In his excellent paper 'British polar expeditions 1919-39' (Polar Record 26(157): 77-84 (1990), John Wright recognizes that he may not have listed every expedition. Here are two that he did not mention: John Homby's expedition to the barren lands northeast of Hudson Bay 1926-27, and Tom Manning's to Southampton Island, 1933-35.

Insofar as Hornby, an Arctic wanderer, had a home base, his expedition was organized in England (although 'organized ' is too strong a word), and included two others - his 18-year old cousin, Edgar Christian, and another young Englishman, Harold Adland, who was recruited in Canada. All three of them died from starvation in a cabin on the Thelon River in spring 1927. The ill-fated expedi- tion gave rise to two classics of polar literature. The diary of Edgar Christian (the last to die by five weeks) was edited by his father, Lt Col W. F. Christian, and published under the title Unflinching in 1937. As a testimony to awesome bravery in the face of lonely death it ranks with Capt Scott's last journal. The original diary is preserved at Edgar's old school, Dover College, where he is commemorated by a brass tablet in the chapel. This information was kindly supplied by Mr R. G. G. Taylor, archivist of the College.

The other book is The Legend of John Hornby (1962) by the late Prof George Whalley of Queen's University, Kingston, Ontario.

As regards Tom Manning, prior to his British Canadian Arctic Expedition 1936-39 (actually 1936-41) he had already spent two years on Southampton Island, travelling partly with Eskimos, but mainly alone, while engaged in survey and zoological work. 